\title{
OPEN Author Correction: An in vitro assay and artificial intelligence approach to determine rate constants of nanomaterial-cell interactions
}

\author{
Edward Price \& Andre J. Gesquiere \\ 2019 \\ The Acknowledgements section in this Article is incomplete. \\ "We thank Michael Miller at W.S.I. for discussion." \\ should read:
}

Correction to: Scientific Reports https://doi.org/10.1038/s41598-019-50208-x, published online 26 September

"We thank Michael Miller at W.S.I. for discussion. We gratefully acknowledge Dr. Tyler Maxwell for his contribution to Figure S11c."

\begin{abstract}
(c) (1) Open Access This article is licensed under a Creative Commons Attribution 4.0 International License, which permits use, sharing, adaptation, distribution and reproduction in any medium or format, as long as you give appropriate credit to the original author(s) and the source, provide a link to the Creative Commons license, and indicate if changes were made. The images or other third party material in this article are included in the article's Creative Commons license, unless indicated otherwise in a credit line to the material. If material is not included in the article's Creative Commons license and your intended use is not permitted by statutory regulation or exceeds the permitted use, you will need to obtain permission directly from the copyright holder. To view a copy of this license, visit http://creativecommons.org/licenses/by/4.0/.
\end{abstract}

(c) The Author(s) 2019 